\title{
MANAGEMENT OF SUSTAINABLE ENTREPRENEURSHIP ADAPTATION TO TAX CHANGES IN ENVIRONMENTAL INVESTMENT
}

\author{
Yaroslav Kvach', Nataliia Piatka ${ }^{2}$, Viktor Koval ${ }^{3}$
}

\begin{abstract}
The article highlights the problem of management of sustainable entrepreneurship adaptation to tax changes in environmental investment and substantiation of the conceptual basis for assessing the efficiency of environmental investment in terms of Ukraine's integration processes into European community that involves introduction of sustainable economic development and mechanisms of "green" economy. Methods. A study of the peculiarities of environmental financing in Ukraine has been conducted. The theoretical bases of investment management have been examined by means of the following methods: semantic analysis of interaction of the basic elements of environmental investment process for sustainable entrepreneurship development. With the use of a comparative analysis of environmental investment, efficiency and effectiveness of environmental tax collection in Ukraine and the EU countries, the expedience of using environmental taxation as a means of stimulating domestic environmental investment has been substantiated and the need to assess the efficiency of environmental investment has been defined. Results. A study of the peculiarities of domestic environmental taxation in order to establish its efficiency has been carried out. The experience of using taxes as a means of stimulating environmental investment in the EU countries has been under consideration. This research has shown that the efficiency of environmental taxes is ensured by their high rates, which encourage companies to innovate and make appropriate environmental investments. A number of shortcomings in the domestic environmental policy have been identified. It has proven the low efficiency of its instruments, in particular, related to assessing the efficiency of environmental investment. A study of the peculiarities of environmental financing in Ukraine has been conducted. The current tendencies of investment in environmental activities with the identification of causal relationships to substantiate management decisions to improve the use of financial resources for environmental purposes have been highlighted.
\end{abstract}

Key words: sustainable entrepreneurship, taxes, taxation, assessing efficiency, adaptation to tax changes, environmental investment.

JEL Classification: H23 J11, Q01, Q56

\section{Introduction}

Permanent climate changes emphasize the importance of developing sustainable entrepreneurship in ensuring the social responsibility of business for the impact on the environment caused by the results of production activities with the purpose to improve the financial position of enterprises. Improving the financial state of enterprises is possible through investment that also contributes to ensuring

\footnotetext{
Corresponding author:

${ }^{1}$ Odessa Institute of Trade and Economics

of Kyiv National University of Trade and Economics, Ukraine.

E-mail: ykvach@ukr.net

ORCID: https://orcid.org/0000-0002-8076-3520

${ }^{2}$ Mukachevo State University, Ukraine.

E-mail: ivanka.kitten@gmail.com

ORCID: https://orcid.org/0000-0001-9810-3961

${ }^{3}$ Odessa Institute of Trade and Economics

of Kyiv National University of Trade and Economics, Ukraine.

E-mail: victor-koval@ukr.net

ORCID: https://orcid.org/0000-0003-2562-4373
}

sustainable development of the national economy and competitiveness of enterprises.

However, having the lack of own sources of funding, the national economy is in demand of investments, which will be one of the most important means to achieve sustainable socio-economic growth, technological re-equipment and greening of manufacturing. European integration processes stimulated creating the preconditions and opportunities for environmental 
management reform in Ukraine, and mainly increased the possibility to solve effectively environmental problems that is the basis for achieving the goals of sustainable development and providing environmental and social guarantees for all entities of national economy (Kostetska et al., 2020).

Increasing of investment amounts into the environmental projects can be a key factor to ensuring economic benefits for businesses and opportunities to obtain positive social and environmental results for the state. Therefore, there is a growing need for intensive investment in environmentally friendly innovations that requires an optimal distribution of available environmental funds, ensuring a maximum effect with the minimum possible financial costs. Achieving the set goals is related to determining the indicators of environmental investment efficiency and level of taxation, which will serve as a basis for making appropriate management decisions.

The necessity of linking the taxation policies to the investment programs for sustainable development and focus of investment development on the needs of sustainable development requires a further study of the management of sustainable entrepreneurship adaptation to tax changes in environmental investment.

\section{Literature review}

The growth of research works on sustainable entrepreneurship and the appearance of various definitions of this term have caused a significant difference in its interpretation. According to Cohen, Winn (2007), Schaltegger, Wagner (2011) and Stubbs (2017), the study of sustainable entrepreneurship involves the analysis of fundamental processes and mechanisms of sustainable development that is directly related to the social development, economics and ecology.

The application of different approaches to the essence of sustainable development of an enterprise does not allow to determine the essential features of this concept, because there is an interdependence between sustainable entrepreneurship and investment processes.

Investing in sustainable development provides the growth of "environmental investment", which means all types of property including intellectual property invested in business and other activities in order to reduce (or avoid) eco-destructive impact on the environment and prevent future income shortfalls from the lost resources that allow moving towards sustainable development (Weidinger, 2014).

The research of environmental investments and their characteristics in order to obtain economic effect and adherence to the principle of prevention within the framework of sustainable development, avoiding eco-destructive effects from production activity have been investigated by Klassen, Vachon (2003), Higgins, Hajkowicz, Bui (2008), Bostian, Färe, Grosskopf,
Lundgren,(2016), Testa et.al. (2016), Mahmood, Furqan, Bagais (2019).

The intensification of environmental investment in the national economy to ensure sustainable development has been considered under various approaches, one of which is taxation (Fullerton, Kim, 2006; Zhao, Zhou, Kuang, 2019; Hassan, Oueslati, Rousselière, 2020). According to the analysed researches, the environmental tax acts as an instrument of environmental protection, however, the efficiency of environmental financing will increase in the case of decentralization of taxation that will bring the priorities of financing as close as possible to the specific environmental problems of certain areas.

The aim is to study the management of the sustainable entrepreneurship adaptation to changes in environmental taxation and substantiation of the conceptual bases for assessing the efficiency of environmental investment in terms of Ukraine's integration processes into the European community that involves introduction of sustainable economic development and mechanisms of "green" economy.

\section{Environmental taxation as an instrument for financing environmental measures}

Environmental investments increase the prospects and importance in ensuring the development of the circular economy, as the implementation of environmental investment will solve a number of important problems and ensure a positive outcome for the environment (Gubanova et al., 2019). The instruments for regulating environmental financing include not only administrative methods of influence (environmental subsidies and benefits; deposit systems of reimbursement and subsidies), but also environmental taxes that are considered to be not only a part of the fiscal policy, but also a part of the environmental policy. The need for cooperation between Ukraine and the EU in the field of environmental policy is indisputable, not only in terms of integration processes, but primarily in order to reduce the environmental pollution.

In contrast, the European Union (EU) countries use environmental taxes as a means of impact on the behavior of business entities, regardless of their belonging either to producers or consumers of certain goods. The collection of data on environmental taxes according to the types of economic activity is a part of Regulation (EU) No 691/2011 of the European Parliament and of the Council of 6 July 2011 on European environmental economic accounts, which provides a basis for developing different types of environmental accounts (Piatka, Kovshun, 2019).

The experience of the EU countries has shown the efficiency of the financial instrument for the environmental policy, which includes additional funding for those companies that have reduced the amount of harmful emissions. 
A special role of product taxes in regulating the level of environmental safety in the EU countries should be noted. Environmental taxes on a product include taxes levied on a unit of a ready-made product that, at one stage of its life cycle, leads to environmental pollution, besides, they may also include: a tax on water pollution, carbon dioxide emissions in the air and others.

Every country uses different regulatory mechanisms, financial and economic mechanisms for solving environmental problems. The main methods and mechanisms for environmental protection used in foreign countries are systematized in Table 1.

Apart from the transport taxes, which exist in the EU countries and are absent in Ukraine, we can mark the absence of noise pollution taxes and food taxes in the state tax system of Ukraine. That is why there are some difficulties in comparing amounts, dynamics and correlation with the main macroeconomic indicators of the EU environmental taxes and environmental taxes in Ukraine.

To consider the problem in detail, we are going to analyze the international data on the amount of environmental tax revenues in the EU, its share in total tax revenues and correlation with gross domestic product (GDP) (Table 2).
In 2018, about 368796 million EUR of environmental tax was collected in the EU that amounted to $5.97 \%$ of the total revenues from taxes and fees and is $2.4 \%$ comparing to EU GDP.

Thus, the total amount of environmental tax in the EU during the period under study shows a steady upward trend, although some fluctuations were marked, but in general it increased by $21.3 \%$ in 2018 in comparison with 2011.

When analyzing the fiscal function of the environmental tax, its share in GDP and in the total amount of tax revenues is important.

Despite the general trend of the totalEU environmental tax increasing in 2018 up to 368796 million EUR, we should note that it is only $5.72 \%$ of all tax payments and social contributions (Figure 1).

The share of funds from the payment of the EU environmental tax for the analyzed period of time ranges from $5.97 \%$ to $6.18 \%$ for the EU-28 and from $5.72 \%$ to $5.89 \%$; for the Eurozone (19 countries) that, on the one hand, characterizes not high profitability but, on the other hand, testifies to stability of the environmental tax payment. It should be noted that this is an average value, as for Eurozone countries, the dynamics is slightly different. Thus, Latvia has the largest share (11.2\%),

Table 1

Main financial mechanisms for environmental protection

\begin{tabular}{|l|c|c|c|c|c|c|c|c|c|}
\hline \multicolumn{2}{|c}{ Taxes, fees and charges } & \multicolumn{7}{c|}{ Countries } \\
\cline { 2 - 14 } & Canada & Finland & France & Germany & Italy & Japan & Sweden & Great Britain & USA \\
\hline Pollution fee: & & & & & & & & & \\
\hline - atmospheric air; & & & + & & & + & & & \\
\hline - water; & & & + & + & + & & & & \\
\hline - waste; & & & & & & & & & + \\
\hline - noise & & & + & + & & + & & + & + \\
\hline Payments for waste collecting and recycling & + & + & + & + & + & + & + & + & + \\
\hline $\begin{array}{l}\text { Environmental tax on the product included } \\
\text { in the production price }\end{array}$ & & + & + & + & + & & + & & + \\
\hline Administrative fees (licenses) & & + & + & + & + & + & + & + & + \\
\hline Subsidies & + & + & + & + & & + & + & & + \\
\hline Environmental insurance & & & + & & + & + & + & + & + \\
\hline
\end{tabular}

Source: compiled by the author on the basis of Eurostat (2018), OECD/EEA (2019)

Table 2

Indicators of environmental taxation in the EU for 2011-2018

\begin{tabular}{|c|c|c|c|c|c|c|c|c|}
\hline \multirow{2}{*}{ Indicators } & \multicolumn{8}{|c|}{ Year } \\
\hline & 2011 & 2012 & 2013 & 2014 & 2015 & 2016 & 2017 & 2018 \\
\hline \multicolumn{9}{|c|}{ Total environmental taxes, million euro } \\
\hline$E U-28$ & 304063 & 317127 & 327511 & 332668 & 344119 & 360146 & 364780 & 368796 \\
\hline Eurozone (19 countries) & 217602 & 229557 & 235135 & 240130 & 245751 & 251161 & 259858 & 265579 \\
\hline \multicolumn{9}{|c|}{ Total amount of tax revenues (\%) } \\
\hline$E U-28$ & 6.17 & 6.18 & 6.16 & 6.13 & 6.14 & 6.13 & 6.11 & 5.97 \\
\hline Eurozone & 5.81 & 5.89 & 5.86 & 5.84 & 5.84 & 5.79 & 5.83 & 5.72 \\
\hline \multicolumn{9}{|c|}{ Gross domestic product (\%) } \\
\hline$E U-28$ & 2.37 & 2.4 & 2.43 & 2.45 & 2.45 & 2.43 & 2.44 & 2.4 \\
\hline Eurozone & 2.28 & 2.34 & 2.39 & 2.41 & 2.42 & 2.38 & 2.4 & 2.37 \\
\hline
\end{tabular}

Source: compiled on the basis of Eurostat data (2018) 


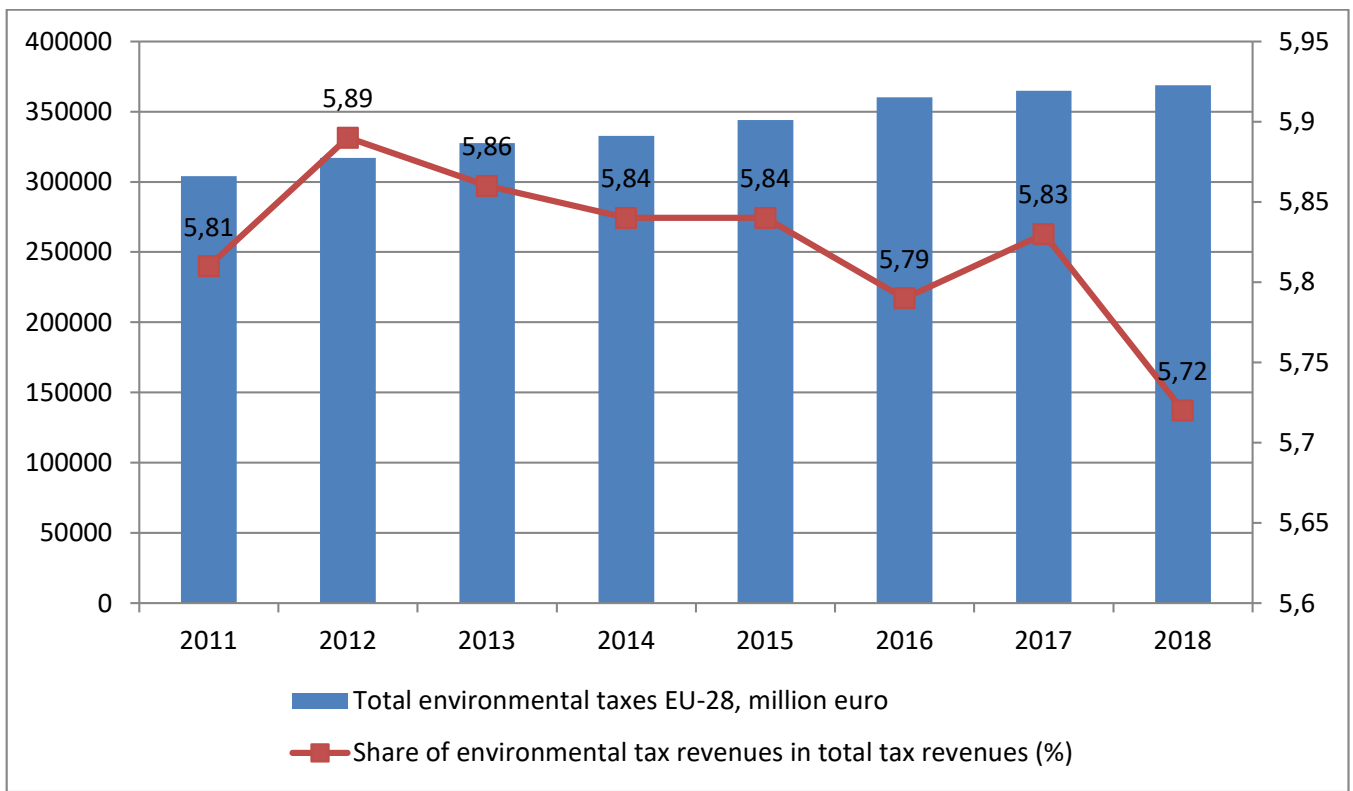

Figure 1. Dynamics of the share of environmental tax revenues in tax revenues of EU countries

Source: compiled on the basis of Eurostat data (2018)

Slovenia and Greece have $10.2 \%$ (both), and such countries as: Luxembourg (4.4\%), Germany (4.6\%), France and Belgium (both $5 \%$ ) have the least funds of environmental tax (Eurostat, 2018).

Thus, the funds from the environmental tax payment to the Consolidated Budget of Ukraine are only $0.50-1.31 \%$ of the total tax revenues, in the State Budget of Ukraine the figures vary between $0.27-1.29 \%$, in local budgets $-0.92-2.29 \%$; that characterizes the scarcity of contributions and shows that the environmental tax in Ukraine is not a budget-forming tax, as its share in total tax revenues remains insignificant and tends to decrease.
An important indicator of the analysis of environmental payments in the $\mathrm{EU}$ is its fiscal efficiency, which is determined by the share of tax in macroeconomic indicators, i.e. the ratio of revenue from the environmental tax and GDP (Figure 2).

Overall, throughout the entire period of study, environmental taxes to GDP (\%), amount from $2.37 \%$ to $2.45 \%$, and in terms of the EU countries, these figures vary from $1.7 \%$ to $3.97 \%$. However, in Ukraine throughout the period of study these figures vary from $0.14 \%$ to $0.30 \%$. It should be noted that in 2018 the amount was $0.14 \%$, it is the lowest value for the period

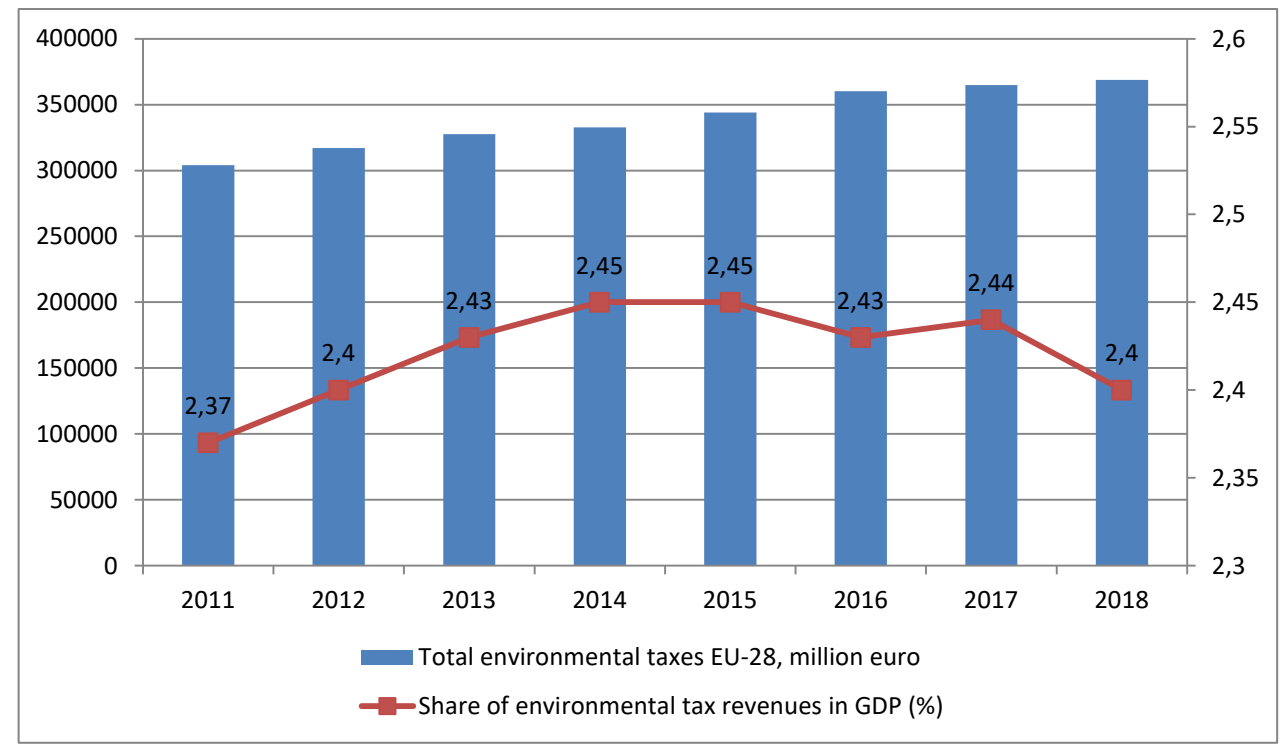

Figure 2. Dynamics of the share of environmental tax revenues in the GDP of EU countries

Source: compiled on the basis of Eurostat data (2018) 
of study. Throughout the period of study from 2011 to 2018, the share of environmental payments has not changed dramatically, although over the past three years a downward trend has been fixed. The share of environmental taxes in GDP in Ukraine remains very low. Certainly, the amount of revenue increases every year, but in terms of both GDP and total tax revenue, the share of environmental payments remains low.

In the EU countries, the share of this tax is much higher, that allows it acting as an instrument for financing environmental measures (Figure 3 ).

A comparative analysis of revenues from environmental taxes has shown that in Ukraine their share is not more than $0.3 \%$ of GDP (ranging from $0.14 \%$ to $0.3 \%$ ), and in the EU an average figure is $2.4 \%$ (ranging from $2.37 \%$ to $2.45 \%$ ). This confirms ineffectiveness of domestic environmental policy and its instruments. A successful combination of principles and means of regulation in the EU provides positive changes in the system of environmental protection.

Since its introduction, the environmental tax has been distributed between the levels of the budget system, according to the law, one part of the environmental tax (except for radioactive waste) is distributed between local and state budgets, another part of environmental tax connected with radioactive wastes is fully directed to the state budget.

The constant increase in environmental tax revenues can be explained by the growth of environmental tax rates, which have been constantly increasing throughout the period of the tax existence. The results of the study of the fiscal function of environmental taxation indicate a low fiscal efficiency of the environmental tax, as the low level of the environmental tax does not encourage investing in expensive environmental equipment.

Today, the environmental tax could be considered as a financial instrument for environmental activities, but the current system of payments to compensate for the negative impact on the environment in Ukraine does not fully meet its fiscal and incentive goals. Therefore, at present, the environmental tax that does not even perform its primary incentive function and is not aimed at achieving specific environmental goals acts as a kind of payment for the use of the natural environment.

The EU countries' experience shows that increasing the efficiency of the environmental taxation system can be achieved by means of the targeted use of accumulated funds and tax benefits, as the revenues from environmental taxation are directed to the development of environmental infrastructure, introduction of environmentally friendly technologies and processes, etc. In addition, in the vast majority of countries, there are effective preferential mechanisms of the taxation and incentives to improve the environmental performance of businesses. Environmental taxes are increasingly used to influence the economic behavior of business entities, as these taxes generate income, which is used later to create programs aimed at promoting the further development of environmental protection.

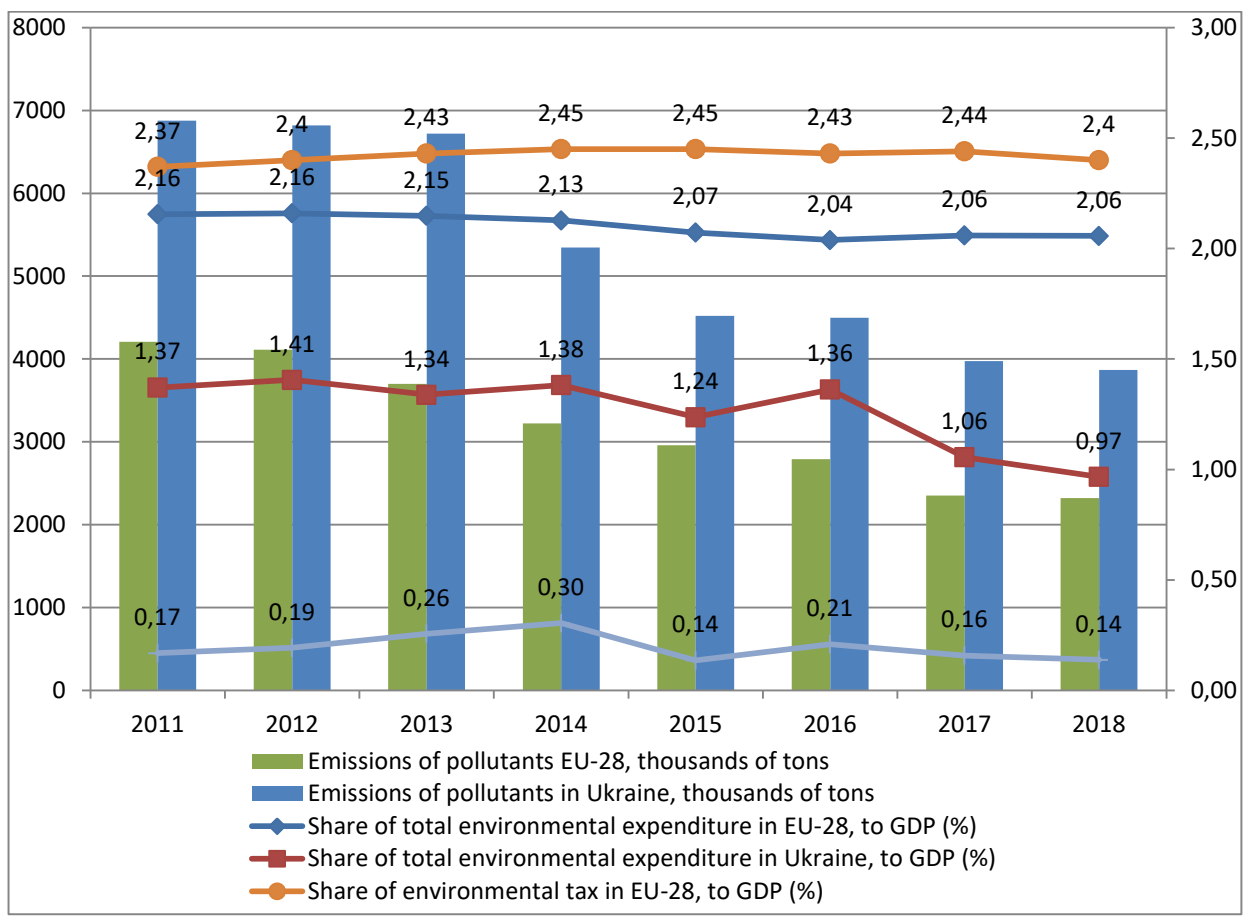

Figure 3. Dynamics of the main indicators characterizing the efficiency of environmental taxation as an instrument for financing environmental measures

Source: compiled on the basis of Eurostat data (2018) 
A foreign experience also shows a conditional division of environmental costs into: mandatory costs regulated by the state and voluntary costs of enterprises and citizens for environmental measures. Today in Ukraine, the environmental tax is not actually used to stimulate investment and innovation in the field of ecology. That is why the economy of Ukraine needs to intensify the processes of environmental investment and increase its scale, as well as raise the efficiency of environmental expenditures. In all successful countries, environmental taxation is an effective financial instrument to stimulate investment and innovation in the field of environmental protection that contributes to improving environmental safety and spreading the innovative technologies. Ukraine should adopt the experience of the countries whose growth is connected with the transfer and commercialization of innovative technologies and creation of financial and economic preconditions for the diffusion of environmental innovations.

Consequently, we should state that it is necessary to change the strategy of environmental investment in Ukraine. In particular, it is necessary to improve the environmental taxation system, to apply the system of tax benefits to business entities that have a positive dynamics in minimizing pollution; in the context of decentralization, it is necessary to review the functions of local environmental funds to intensify environmental investment.

\section{Systematization of international experience of environmental investment}

In the context of current aggravation of ecological contradictions both on global and national scales, development of modern methods concerning rationalizing the use of natural resources is getting a vital importance. As the world practice shows, it is possible to achieve breakthrough results in slowing down the degradation processes in the field of nature management by involving natural resources in the reproduction process. Moreover, a special mechanism for managing environmental funds should be formed. It would take into account the fundamental principles of tax regulation of the use of natural resources and environmental protection, and forms / methods of financing capital investments and current expenditures in reproduction and environmental protection processes. Measuring the financial and economic obligations to protect the environment helps to assess how environmental expenditures affect international competitiveness and to assess the application of the "polluter pays" principle and the cost-effectiveness of the environmental control mechanism (Nazarova et al., 2019).

In the process of Ukraine's integration into the EU, it is extremely important to study the current state of environmental investment in the EU. In foreign countries, the environmental measures have gradually been changing from pollution clean-up to pollution prevention policies, increasing the internationalization of corporations environmental measures by modifying industrial processes that coincide with the growing demand for "cleaner" products. Currently, the environmental protection measures are aimed at fighting against climate change, reducing air pollution and preserving biodiversity (OECD / EEA, 2019).

In the EU countries, funding for environmental measures is provided from the following sources, such as: public administration (direct funding for measures), households (establishment of an alternative energy source for self-consumption by a separate stakeholder group), producers of environmental services, corporations - business representatives (grant support in the field of environmental protection).

According to the data of Eurostat (2018), in 2018 the national expenditures of the EU-28 on environmental protection amounted to 316 billion EUR that is considered to be $23.5 \%$ more than in 2006 , i.e. there was a steady increase by an average of $2 \%$ each year (Figure 4 ).

Examining the amount of national expenditure on the environmental protection in terms of institutional sectors, it should be noted that the largest contribution to the amount of costs was made by corporations. It accounted for $54 \%$ of total EU expenditure on the environmental protection in 2018. At the same time, the expenditures of general governmental and non-profit institutions serving households amount only $24 \%$, and the expenditures of households amount $22 \%$ of the EU total national expenditure on the environmental protection in 2018.

During the period of study, the share of the EU national environmental expenditure (as a percentage to gross domestic product) remained relatively stable and ranged from $1.86 \%$ to $2.07 \%$. In 2006, the share of the EU national environmental expenditure in GDP was $1.98 \%$, with a slight increase to $2.7 \%$ in 2009 ; it mainly occurred as a result of large GDP reduction during the financial crisis and economic downturn. Since 2009, there has been a tendency to reduce the share of the EU national environmental expenditure in GDP. In 2018 it reduced even to $1.87 \%$.

Overall, during the period under review we have observed an increase in the total amount of expenditures on environmental protection. It is worth mentioning that in 2006 the expenditures on environmental protection have been carried out equally at the expense of both governmental and non-profit institutions that serve households and the households themselves, but since 2007 there has been an annual increase in household expenditures and a decrease in governmental expenditures.

A comparative analysis of the share of environmental expenditures in GDP in the EU and Ukraine through a certain time period (2006-2018) will be conducted (Figure 5). 


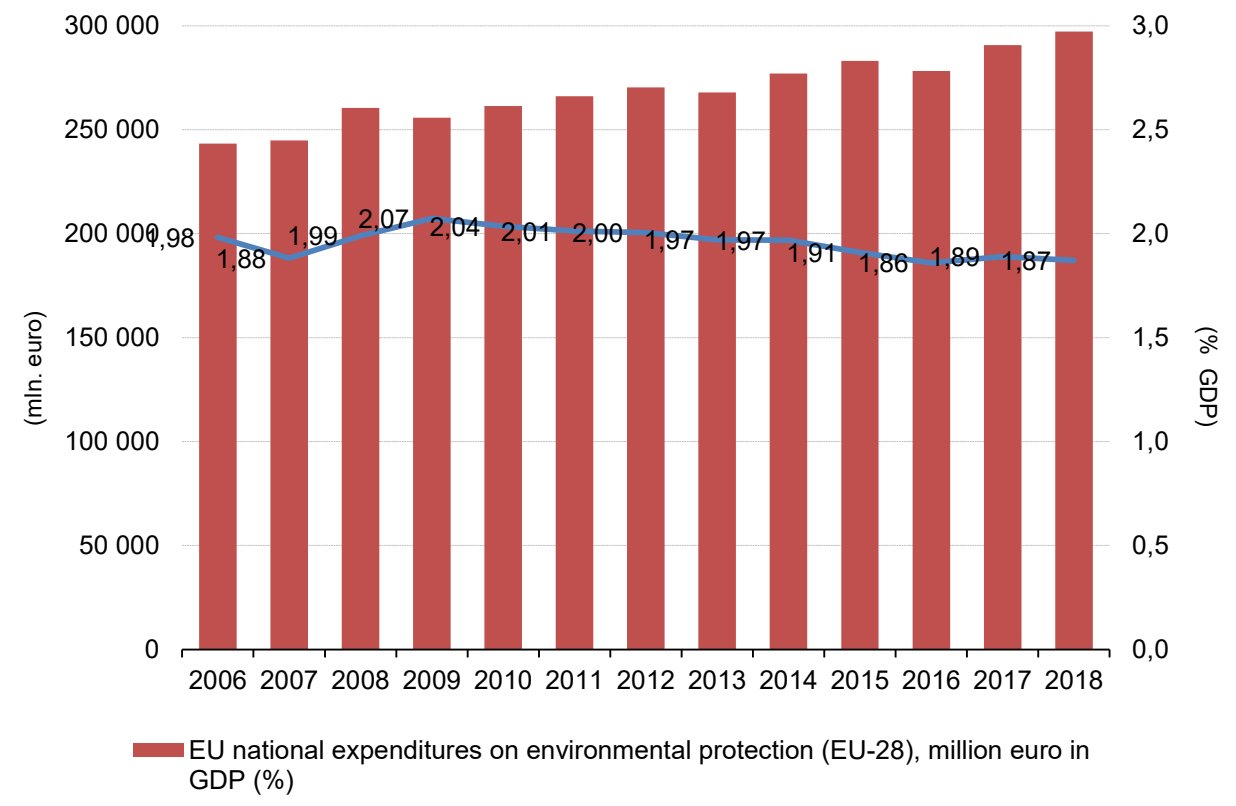

Figure 4. Dynamics of the EU national expenditures on environmental protection and their share in GDP

Source: compiled on the basis of Eurostat data (2018)

After a slight increase in 2009 to $2.07 \%$ of GDP, mainly due to a significant reduction in GDP during the financial crisis and the economic downturn, the correlation of environmental expenditures (EU-28) to GDP slowly decreased, reaching $2.04 \%$ in 2015. But during the last two years it has shown a constant indicator at the level of $2.06 \%$. The share of domestic environmental expenditures in GDP for the period under review ranged within $1 \%$.

Thus, we can state that in Ukraine the share of total environmental expenditures is actually twice less than in the EU (EU-28). And the revealed tendency characterizes recklessness and unreasonableness of funding for environmental expenditures.

It should be noted that due to the significant impact of ecology on the economy, such minimal costs for environmental protection does not lead to increased material well-being and high quality of life. From the standpoint of sustainable development, which embraces environmental, social and economic aspects, the optimal cost is $10 \%$ of GDP (Drahan, 2011).

Thus, during the research, the sufficient nonconformities were revealed. They were fixed between the components and main tendencies as

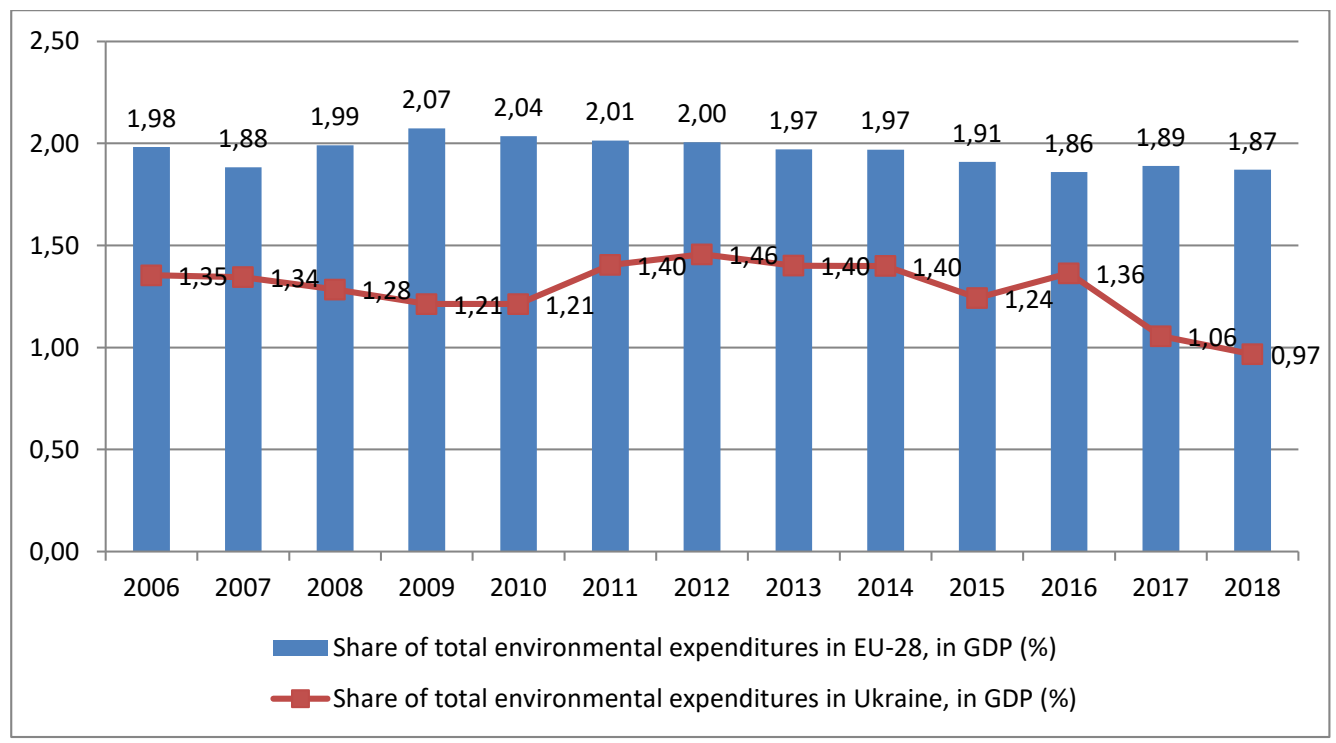

Figure 5. Share of total environmental expenditures in Ukraine and the EU in GDP (\%)

Source: compiled on the basis of Eurostat data (2018) 
for development of expenditures on environmental protection in the EU countries and Ukraine. The analysis of the investment component of environmental expenditures will be conducted (Yankovyi et al., 2020). According to Eurostat (2018), the investment expenditures include: the corporations and public administration expenditures on construction of infrastructure, acquisition of land and equipment necessary for the provision of environmental services. These investment expenditures include, for example, expenditures on waste water treatment plants, waste transport vehicles and acquisition of land to create a nature reserve or of cleaner production equipment with lower polluting emissions (Eurostat, 2018). In 2018, the majority of the EU investments was directed to the main assets for the provision of environmental services or to the so-called "cleaner technologies" (63\%) which were fulfilled by corporations as specialized providers of environmental services (private waste collecting and recycling companies, as well as sewerage companies) and other corporations, investing in technology and equipment, reducing the harmful impact on the environment that appears due to the production processes of these companies (for example, investing in equipment that reduces emissions) (OECD / EEA (2019).

Corporate investment expenditures in 2018 amounted to 37 billion EUR, compared to 27 billion EUR spent by public administration bodies and social service organizations, herewith the investment amounting was more than 63 billion EUR (Table 3).

However, during the period from 2006 to 2018, investment amounts in the corporation environmental protection decreased by $8.4 \%$, while investment amounts in environmental protection of the public administration sector remained relatively stable.
From 2006 to 2018, the share of investments in environmental protection within the total EU investment amounts had an average decrease of $1.1 \%$. The share of investments in environmental protection of governmental and non-profit institutions within the total EU investments ranged from $5.77 \%$ to $6.83 \%$. The share of investments in corporate environmental protection within the total investments is relatively low; in 2018 it was $1.79 \%$, having a reduction by 0.77 percentage points since 2006. The equivalent share in the public administrative sector is higher and amounted to $5.92 \%$ in 2018 , having a reduction by 0.91 percentage points since 2006 . Source is compiled on the basis of Eurostat data (2018).

To obtain the comparable data on Ukrainian and the EU environmental investment it is necessary to conduct a study of specific features of environmental investment in these countries, by comparing the expenditures on environmental protection and dynamics of capital investment to identify the link between environmental investment and the state of the environment.

A graphical comparative analysis of the dynamics of the share of investment in environmental protection within the total capital investment in Ukraine and the EU (Figure 6) has been conducted. It has shown that the share of investment in the environmental protection within the total capital investment of the EU-28 during the period under review has certainly changed. However, its fluctuations have not been as sharp as in Ukraine. The share of investment in the environmental protection within the total capital investment of the EU-28 ranges from $2.48 \%$ to $3.40 \%$ and the average value for the period under study is $2.99 \%$. The average value for Ukraine is $2.25 \%$.

Considering the share of investment within the total expenditures on environmental protection in the EU

Table 3

The EU environmental investment

\begin{tabular}{|c|c|c|c|c|c|c|}
\hline \multirow{2}{*}{ Year } & \multicolumn{2}{|c|}{$\begin{array}{l}\text { Governmental and non-profit institutions } \\
\text { that serve households }\end{array}$} & \multicolumn{2}{|c|}{ Corporations } & \multirow{2}{*}{$\begin{array}{c}\text { Total } \\
\text { environmental } \\
\text { investment, } \\
\text { million euro }\end{array}$} & \multirow{2}{*}{$\begin{array}{c}\text { Growth rate } \\
(\%)\end{array}$} \\
\hline & $\begin{array}{l}\text { Investment amounts, } \\
\text { million euro }\end{array}$ & $\begin{array}{l}\text { A share of total } \\
\text { investment, } \%\end{array}$ & $\begin{array}{l}\text { Investment amounts, } \\
\text { million euro }\end{array}$ & $\begin{array}{l}\text { A share of total } \\
\text { investment, } \%\end{array}$ & & \\
\hline 2006 & 26296 & 6.83 & 40379 & 2.56 & 66675 & - \\
\hline 2007 & 25892 & 6.26 & 40026 & 2.32 & 65918 & -1.14 \\
\hline 2008 & 28258 & 6.36 & 40046 & 2.33 & 68304 & 3.62 \\
\hline 2009 & 26977 & 5.88 & 36959 & 2.60 & 63936 & -6.39 \\
\hline 2010 & 25707 & 5.77 & 36825 & 2.50 & 62532 & -2.20 \\
\hline 2011 & 25321 & 5.89 & 36281 & 2.31 & 61602 & -1.49 \\
\hline 2012 & 25932 & 6.31 & 36364 & 2.25 & 62296 & 1.13 \\
\hline 2013 & 25120 & 6.30 & 34674 & 2.17 & 59794 & -4.02 \\
\hline 2014 & 25498 & 6.25 & 34175 & 2.02 & 59673 & -0.20 \\
\hline 2015 & 28239 & 6.61 & 38530 & 2.08 & 66769 & 11.89 \\
\hline 2016 & 23153 & 5.77 & 34076 & 1.78 & 57229 & -14.29 \\
\hline 2017 & 26102 & 6.16 & 36612 & 1.84 & 62714 & 9.58 \\
\hline 2018 & 26726 & 5.92 & 36991 & 1.79 & 63717 & 1.60 \\
\hline
\end{tabular}

Source: compiled on the basis of Eurostat data (2018), OECD/EEA (2019) 


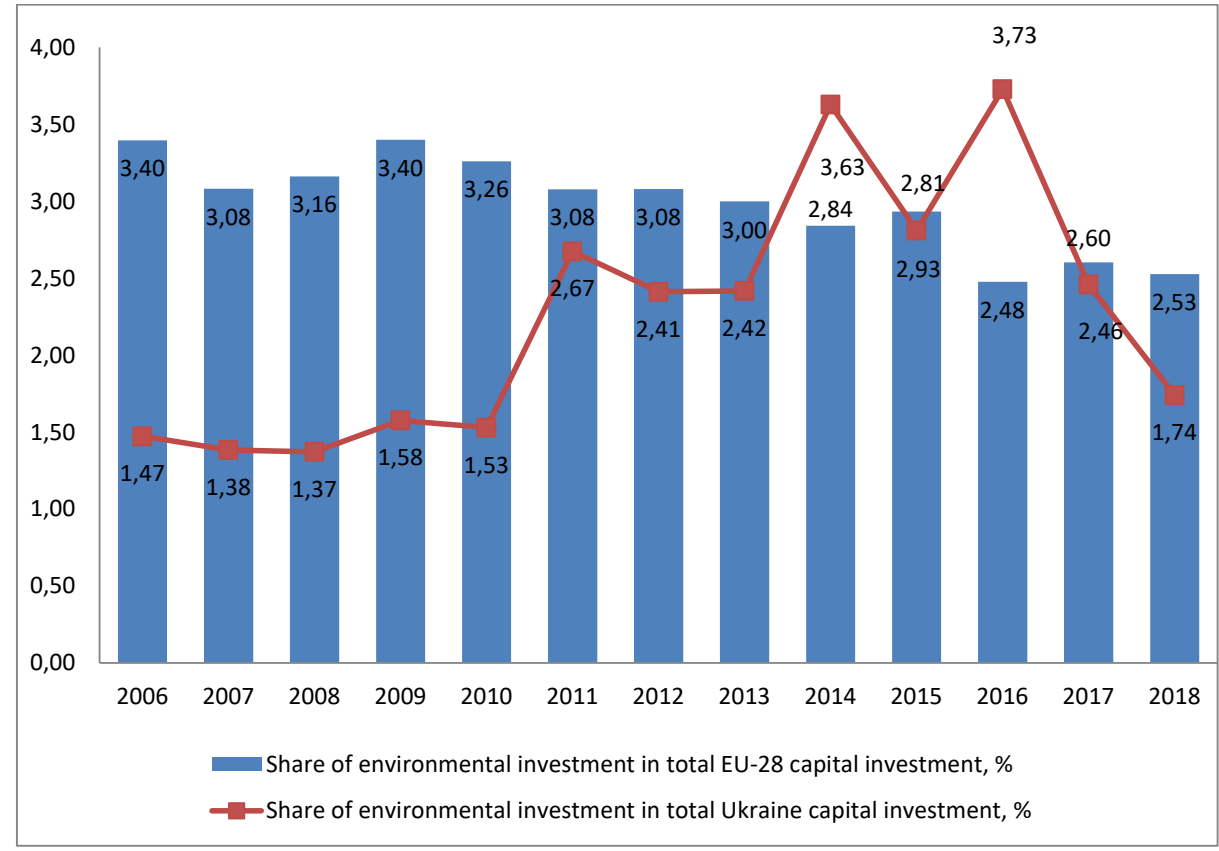

Figure 6. Share of environmental investment in total Ukraine and the EU capital investment, \%

Source: compiled on the basis of Eurostat data (2018), OECD/EEA (2019)

and Ukraine, it should be noted that in Ukraine this figure is much higher. In Ukraine, a share of capital investment in the environmental protection within the total environmental expenditures is higher than in Europe.

Thus, the conducted analysis of the environmental protection expenditures and investments shows that in Ukraine the share of these indicators is higher, however, the efficiency of their use does not allow to ensure a favourable state of the environment that determines the need to intensify greening processes not only by increasing the scale of environmental investment, but by increasing the efficiency of its use, i.e. the introduction of stimulating levers of influence (Figure 7).

The conducted analysis has shown that the economic instruments used to control the environmental pollution

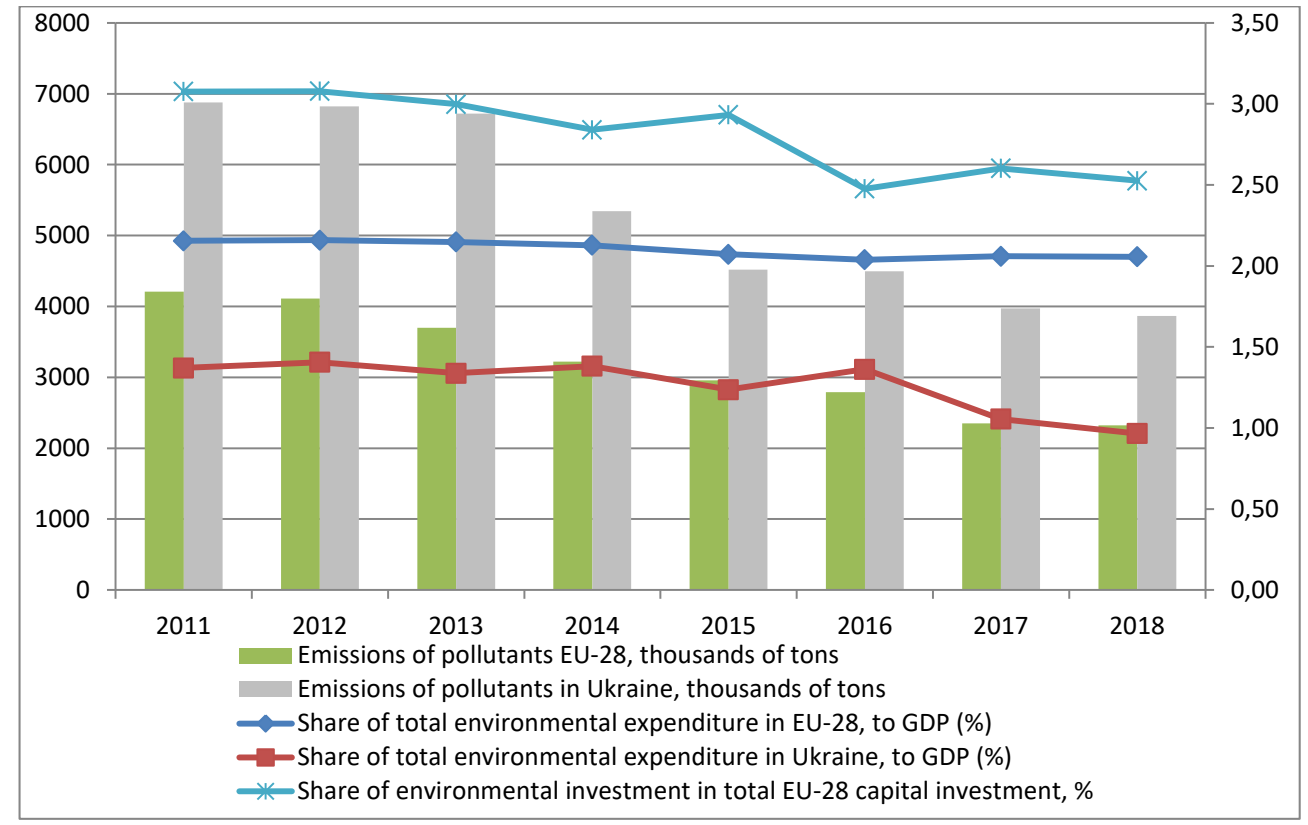

Figure 7. Dynamics of the main indicators that characterize the efficiency of environmental investments Source: compiled on the basis of Eurostat data (2018), OECD/EEA (2019), State Statistics Service of Ukraine (2019) 
and rational use of natural resources, play an important role in the EU's environmental policy.

A set of instruments and methods of influencing the producers and consumers is quite wide. It includes: environmental taxes, fees and mandatory payments; trade permits and quotas; environmental subsidies and benefits; deposit systems of reimbursement and subsidies; various schemes of liability and compensation.

\section{Conclusions}

The conducted analysis has shown that the environmental taxes are used in the EU countries as a means of influencing the behavior of economic entities. The main function is to regulate their activities and to give opportunities for sustainable entrepreneurship. The experience gained by foreign countries can be effectively used in Ukraine to create an incentive system to intensify the environmental investment into the national economy to ensure sustainable development. The effectiveness of environmental financing will increase in case of increasing the share of environmental tax deductions and rent fees for the special use of natural resources to local government budgets that will bring the funding priorities as close as possible to the specific environmental problems of the certain areas.

\section{References:}

Bostian, M., Färe, R., Grosskopf, S., \& Lundgren, T. (2016). Environmental investment and firm performance: A network approach. Energy Economics, 57, 243-255.

Cohen, B., \& Winn, M. I. (2007). Market imperfections, opportunity and sustainable entrepreneurship. Journal of business venturing, 22(1), 29-49.

Drahan, I. O. (2011). Analysis of foreign experience of investment and innovation support of state environmental policy. Naukovyi visnyk akademii munitsypalnoho upravlinnia, 2, 50-60. (in Ukrainian)

Eurostat (2018). General and regional statistics. Available at: http://ec.europa.eu/eurostat

Fullerton, Don \& Kim, Seung-Rae (2006). Environmental investment and policy with distortionary taxes, and endogenous growth. Journal of Environmental Economics and Management, 56, 141-154. doi: 10.1016/ j.jeem.2008.02.001

Gubanova, E., Kupinets, L., Deforzh, H., Koval, V., \& Gaska, K. (2019). Recycling of polymer waste in the context of developing circular economy. Architecture Civil Engineering Environment, 12(4), 99-108. doi: 10.21307/ACEE2019-055

Hassan, M., Oueslati, W., \& Rousselière, D. (2020). Environmental taxes, reforms and economic growth: An empirical analysis of panel data. Economic Systems, 44(3), 100806.

Higgins, A. J., Hajkowicz, S., \& Bui, E. (2008). A multi-objective model for environmental investment decision making. Computers \& operations research, 35(1), 253-266.

Klassen, R. D., \& Vachon, S. (2003). Collaboration and evaluation in the supply chain: The impact on plant level environmental investment. Production and operations Management, 12(3), 336-352.

Kostetska, K., Khumarova, N., Umanska, Y., Shmygol, N., \& Koval, V. (2020). Institutional qualities of inclusive environmental management in sustainable economic development. Management Systems in Production Engineering, 28(2), 15-22. doi: $10.2478 / \mathrm{mspe}-2020-0003$

Mahmood, H., Furqan, M., \& Bagais, O. A. (2019). Environmental accounting of financial development and foreign investment: spatial analyses of East Asia. Sustainability, 11(1), 13.

Nazarova, K., Hordopolov, V., Kopotiienko, T., Miniailo, V., Koval, V., \& Diachenko, Y. (2019). Audit in the state economic security system. Management Theory and Studies for Rural Business and Infrastructure Development, 41(3), 419-430.

OECD/EEA (2019). Database on instruments used for environmental policy and natural resources management. Available at: http://www2.oecd.org/ecoinst/queries

Piatka, N.S., \& Kovshun, N.E. (2019). Environmental taxation as a tool for financing environmental measures. Modern trends in the development of financial and credit system: theory and practice. Poltava: PP "Astraya".

Schaltegger, S., \& Wagner, M. (2011). Sustainable entrepreneurship and sustainability innovation: categories and interactions. Business strategy and the environment, 20(4), 222-237.

State Statistics Service of Ukraine (2019). Statistical Yearbook of Ukraine for 2018. Available at: https://ukrstat.org/en Stubbs, W. (2017). Sustainable entrepreneurship and B corps. Business Strategy and the Environment, 26(3), 331-344. Testa, F., Gusmerottia, N. M., Corsini, F., Passetti, E., \& Iraldo, F. (2016). Factors affecting environmental management by small and micro firms: The importance of entrepreneurs' attitudes and environmental investment. Corporate Social Responsibility and Environmental Management, 23(6), 373-385.

Weidinger, C. (2014). Sustainable Entrepreneurship Business Success through Sustainability. Springer.

Yankovyi, O., Koval, V., Trokhymets, O., Karpenko, M., \& Matskevich, Y. (2020). Economic assessment of investment on the basis of production functions. Turismo: Estudos \&Práticas.

Zhao, Y., Zhou, J., \& Kuang, H. (2019). Environmental tax on directed technological innovation in a green growth model. Environmental Engineering \& Management Journal, 18(9), 2045-2054. 